\title{
New species of the rugose coral genus Lithostrotion Fleming in the upper Viséan from the Azrou-Khenifra Basin (Morocco)
}

\author{
Sergio RODRÍGUEZ ${ }^{1,2 *}$, Ian D. SOMERVILLE $E^{3} \&$ Ismail SAID ${ }^{4}$
}

${ }^{1}$ Departamento de Paleontología, Facultad de Ciencias Geológicas, UCM, c/José Antonio Novais, 2. 28040 Madrid (Spain); sergrodr@geo.ucm.es

${ }^{2}$ Departamento de Geología Sedimentaria y Cambio Medioambiental, Instituto de Geociencias, CSIC, UCM, c/José Antonio Novais, 2. 28040 Madrid (Spain)

${ }^{3}$ UCD School of Earth Sciences, University College Dublin, Belfield, Dublin 4 (Ireland); Ian.Somerville@ucd.ie

${ }^{4}$ Direction de la Géologie, Division de la Géoinformation et Publications, Service du Patrimoine Géologique et des Musées, Rue Abou Marouane Essadi BP: Rabat Instituts 6208 - Haut Agdal, Rabat (Morocco)

* Corresponding author

Rodríguez, S., Somerville, I.D. \& Said, I. 2017. New species of the rugose coral genus Lithostrotion Fleming in the upper Viséan from the Azrou-Khenifra Basin (Morocco). [Nueva especie del género Lithostrotion Fleming del Viseense superior de la Cuenca de Azrou-Khenifra (Marruecos)]. Spanish Journal of Palaeontology, 32 (1), 27-34.

\begin{abstract}
The new species Lithostrotion termieri Rodríguez \& Somerville is described. It shows very large corallites of the rugose genus Lithostrotion Fleming. It has been recorded up to now only in upper Viséan rocks from the type locality, the Akrab ridge, Morocco also called Tizi Ben Zizouit by Termier \& Termier (1950), who identified it as Lonsdaleia floriformis, and south-east from Tabainout, also from the Azrou-Khenifra Basin.
\end{abstract}

Keywords: Rugosa, Azrou-Khenifra Basin, systematics, Carboniferous, Morocco.

\section{RESUMEN}

Se describe la nueva especie Lithostrotion termieri Rodríguez \& Somerville. La nueva especie presenta coralitos mayores que cualquier especie previamente descrita del género Lithostrotion Fleming. La especie ha sido recolectada en la loma de Akrab, Marruecos también llamada Tizi Ben Zizouit por Termier \& Termier (1950), quienes identificaron un ejemplar como Lonsdaleia floriformis.

Palabras Clave: Rugosa, Azrou-Khenifra Basin, sistemática, Carbonífero, Marruecos. 


\section{INTRODUCTION}

The present paper deals with the description of a new species of Lithostrotion Fleming that has been recorded in the ridge of Akrab, $10 \mathrm{~km}$ to the north-west of M'rirt, and from olistolites south-east of Tabainout, both in the Azrou-Khenifra Basin, Central Morocco. This discovery was part of our continued research on Carboniferous corals from Morocco.

Termier \& Termier (1950) identified and figured some upper Viséan colonial rugosans as Lonsdaleia floriformis (p. 94, plate XLII, figs 1-3, 10 and plate XLIV, figs 4-5). However, according to our research, the genus Lonsdaleia seems to be totally absent in the Azrou-Khenifra Basin. Termier \& Termier (1950) cited it from four different localities in North Africa: Tizi Ben Zizouit, Bou Guergour, Igli and Tarhit (Figs 1a-b). In addition, one specimen labelled as Lonsdaleia floriformis and collected by Henri Termier in the locality of Tizi Ben Zizouit is stored in the Museum of the Division du Patrimoine Géologique (DPG) of the Ministère de l'Énergie, des Mines, de l'Eau et de l'Environnement in Rabat. We had the opportunity to check the specimen and confirm that it does not belong to that genus and species, but it is a Lithostrotion species having very large corallites. Its detailed study by means of thin sections could not be made because cutting the Museum specimen was not allowed.

On the other hand, some of the thin sections of the Termier collection are housed in the Muséum national d'Histoire naturelle (MNHN), Paris. A search on that collection made by one of us (SRG) established that a single thin section is preserved there: the specimen figured in plate XLII, fig. 1 recorded from Bou Guergour. It is not Lonsdaleia floriformis, but Lithostrotion vorticale having 20-21 septa, $3.5 \mathrm{~mm}$ in tabularium diameter, absence of lonsdaleoid dissepiments and simple columella. Consequently, the search for possible Lonsdaleia should be done by recording additional specimens from the localities cited by Termier \& Termier (1950).

Tarhit (or Targit) is a small village located in the Béchar Basin (Algeria), where Semenoff-Tian-Chansky (1974) recorded several solitary rugose corals in upper Viséan rocks. Unfortunately, at present, it is not possible to visit the locality.

Igli is located in the Moroccan Anti-Atlas, but the identification of the coral locality is not precise: $8 \mathrm{~km}$ north of Igli. The area north from Igli is covered by a large Quaternary alluvial fan and there are no Carboniferous outcrops $8 \mathrm{~km}$ north of Igli.

Bou Guergour is a hill located to the southeast of Khenifra and it is also called Bou Oussel. Ordovician sandstones are dominant there. However, it is bordered to the Southeast by Mississippian rocks containing reef facies that we described in detail from the vicinity of the village of Tiouinine (Rodríguez et al., 2012; Said et al., 2013). Despite recovering a very diverse coral assemblage, including many colonial corals in Tiouinine, neither Lonsdaleia nor large Lithostrotion have been recorded there.

Finally, the Tizi Ben Zizouit locality was precisely located by Termier et al. (1975) on the Akrab Ridge,

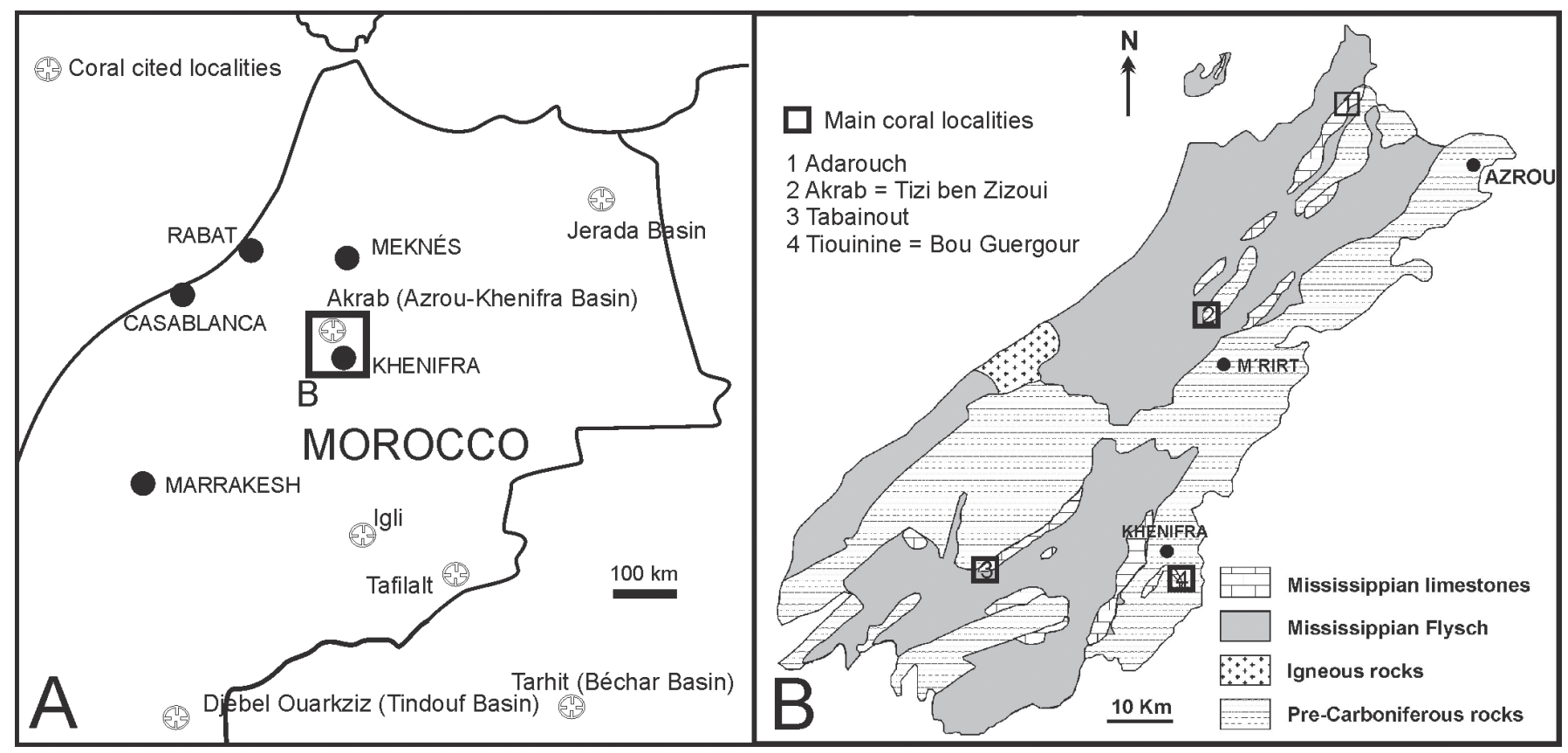

Figure 1. Location of the coral localities cited in the text. a) General map of Morocco and North Algeria. b) Azrou-Khenifra Basin with location of the main coral occurrences (modified from Somerville, et al., 2012; Rodríguez et al., 2016a). 
$10 \mathrm{~km}$ northwest of M'rirt. We collected several cerioid colonial specimens which seem very similar to that housed in the DPG from Rabat. Detailed study of those specimens proved that they belong to a previously undescribed species of Lithostrotion.

The coral assemblage from Akrab, in addition to Lithostrotion termieri, is composed of Lithostrotion araneum (McCoy, 1844), Siphonodendron intermedium Poty, 1981, Siphonodendron martini (Milne-Edwards \& Haime, 1851), Siphonophyllia samsonensis (Salée, 1913), Clisiophyllum garwoodi (Salée, 1913), Axophyllum sp. and Zaphrentites sp. The assemblage is typically upper Viséan in age, as previously determined by Termier \& Termier (1950) and Termier et al. (1975). But no detailed study on other biostratigraphically reliable groups (foraminifers, conodonts) has been made. Thus, provisionally, we maintain that dating without further precisions.

A second locality in the Azrou-Khenifra Basin where Lithostrotion termieri has been recorded, is southeast of Tabainout, from olistolite blocks. It occurs with Siphonodendron martini and Lithostrotion decipiens (McCoy, 1849) of upper Viséan age.

\section{SYSTEMATIC PALAEONTOLOGY}

The terminology used for the description is that proposed by Hill (1981) with some observations of Poty (1981). The microstructural description is based on the terminology of Semenoff-Tian-Chansky (1974) and Rodríguez (1984).

Phylum COELENTERATA Frey \& Leuckart, 1847

Class ANTHOZOA Ehrenberg, 1834

Subclass RUGOSA Milne-Edwards \& Haime, 1850

Family Lithostrotionidae d'Orbigny, 1852

Genus Lithostrotion Fleming 1828

Diagnosis. (After Poty, 1981). Cerioid colonial coral. Major septa long, extending to the axis and commonly connected to the columella. Minor septa extending to the inner edge of the dissepimentarium or slightly entering the tabularium. Columella lath-like, connected to the counter septum. Dissepimentarium of various widths, made of simple interseptal dissepiments and occasional lonsdaleoid dissepiments. Tabulae incomplete. Axial tabulae conical and peripheral tabulae horizontal or declined toward the dissepimentarium. Increase lateral and non-parricidal.

Lithostrotion termieri Rodríguez \& Somerville sp. nov. (Figs 2-3)

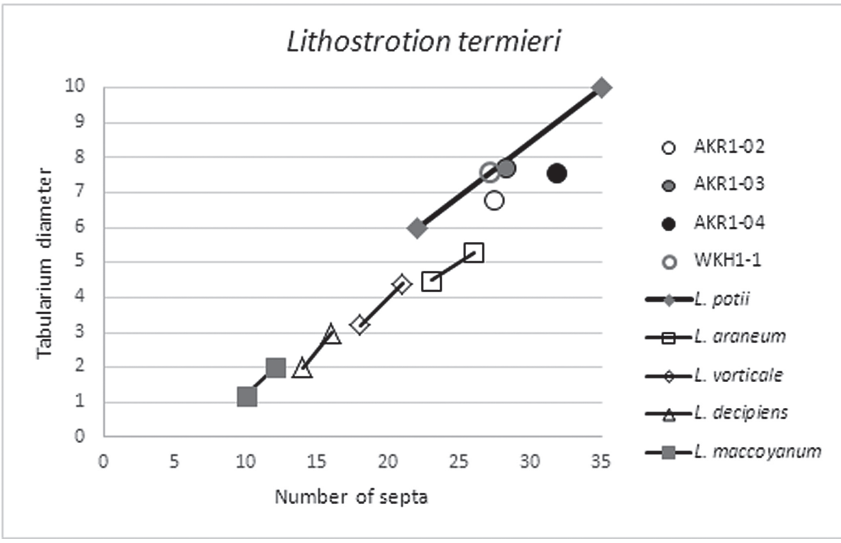

Figure 2. Tabularium diameter $v s$ number of major septa relationship in the main species of Lithostrotion from Central and Western Palaeotethys compared with the studied specimens (data compiled from many sources).

\section{Synonymy.}

Non 1950 Lonsdaleia floriformis Milne-Edwards \& Haime; H. Termier \& G. Termier, p. 94, plate 42, figs $1-3,10$.

? 1950 Lonsdaleia floriformis Milne-Edwards \& Haime; H. Termier \& G. Termier, p. 94, plate 44, figs 4-5.

Derivatio nominis. The name of the species refers to Henri and Geneviève Termier, who first collected specimens of this species and identified them as Lonsdaleia floriformis.

Holotype. Specimen AKR1-2; rest of the specimens collected in the same bed are regarded as paratypes, as is the specimen from Tabainout (WKH1-1).

Type locality, horizon and age. Akrab ridge, $2 \mathrm{~km}$ north of Ighrem Aguerd n'azdayet, $10 \mathrm{~km}$ north-west of M'rirt, Azrou-Khenifra Basin, north central Morocco, upper Viséan. This locality was called Tizi Ben Zizouit by Termier \& Termier (1950).

Material. 4 colonies (DPM AKR1-2, 3, 4, WKH1-1), 14 transverse sections (two from holotype), 8 longitudinal sections (three from holotype). Stored in the Departamento de Paleontología, Universidad Complutense de Madrid. One additional specimen collected by Henri Termier is stored in the Museum of the Division du Patrimoine Géologique (DPG), Direction du Développement Minier (DDM), Ministère de l'Énergie, des Mines, de l'Eau et de l'Environnement, Rabat and numbered A48J48.

Diagnosis. Lithostrotion having 6.5 to $8.0 \mathrm{~mm}$ tabularium diameter and 27 to 32 major septa as a mean 

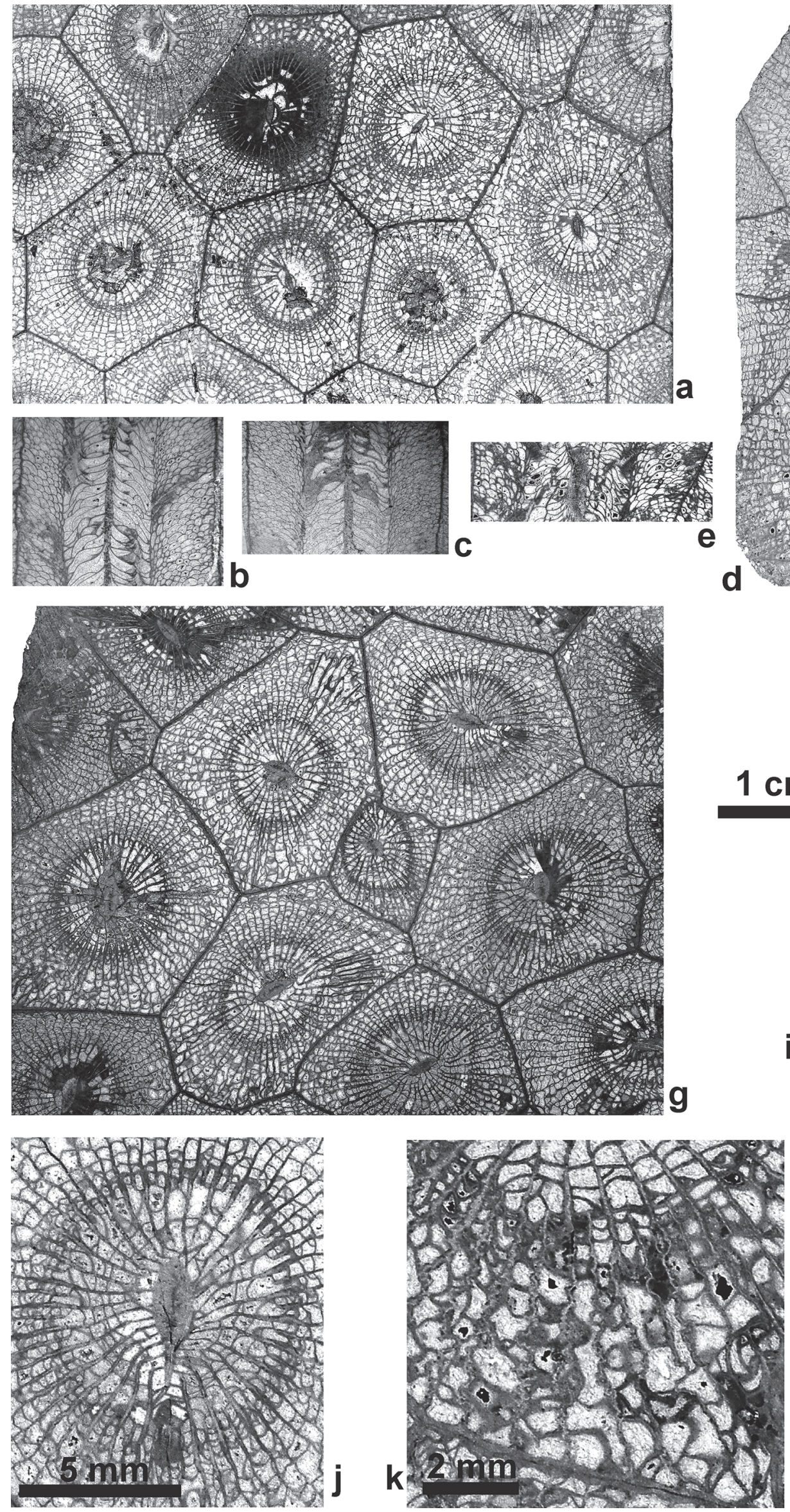
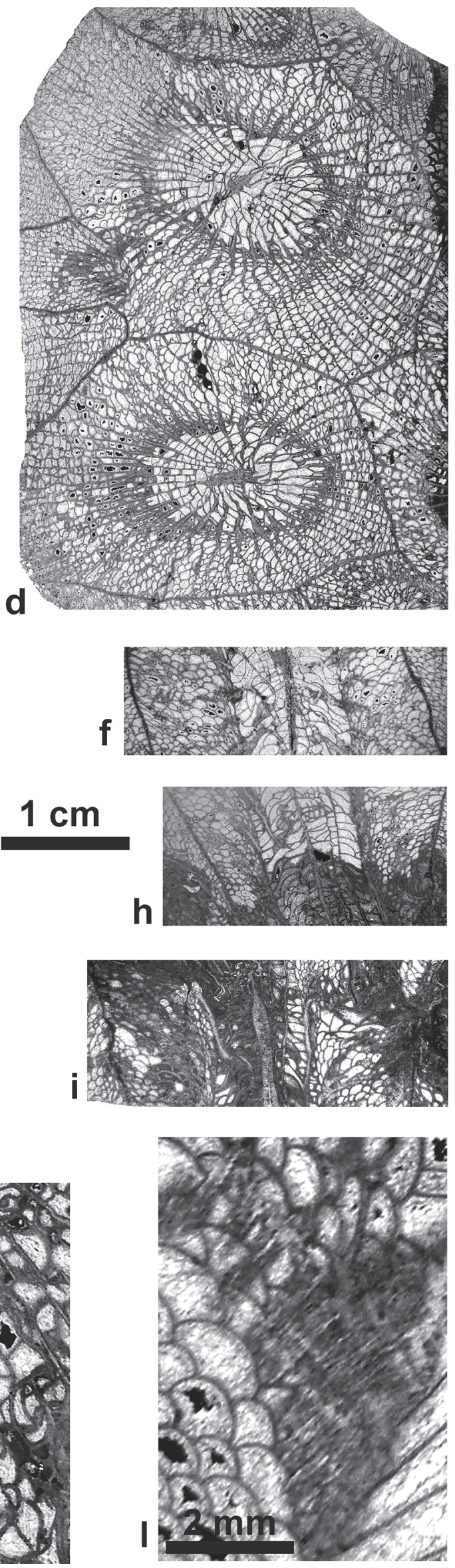
of each colony. Shortened cardinal septum and thickened columella. Moderate thickenings of major and minor septa at the boundary between dissepimentarium and tabularium. 8-10 rows of regular dissepiments that are closely packed near the tabularium. Some irregular dissepiments, including some lonsdaleoid type may occur in the periphery. Trabecular microstructure of wall and septa.

\section{Description.}

External characteristics. Hemispheric to tabular colonies between 10 and $20 \mathrm{~cm}$ in diameter and between 5 and $10 \mathrm{~cm}$ high. Corallites are polygonal, having 4 to 8 sides. The calices show a peripheral platform and a central depression in which an axial, low protuberance stand out. The tabularium diameter varies in adult stage from 6.0 to $8.5 \mathrm{~mm}$. The mean tabularium diameter of each colony varies between 6.8 and 7.8 (Fig. 2; Table 1).

Internal characteristics. The number of major septa varies in adult stages between 26 and 33. The mean of each colony varies between 27.4 and 31.8 (Fig. 2; Table 1). The septa are long, many of them reaching the columella (Figs 3a, d, g, j). They are straight to slightly sinuous in the tabularium and more sinuous to zig-zag in the dissepimentarium (Fig. 3k). Major septa are spindleshaped, moderately thickened in the inner part of the dissepimentarium and external part of the tabularium (Figs 3a, d, g, j, k). The minor septa are also thickened, notably where they penetrate slightly in the tabularium, but not as thick as majors. The cardinal septum is somewhat shortened in most mature corallites and located in a small cardinal fossula (Fig. 3j). In some cases, the cardinal septum reaches the inner ring of tabulae close to the columella, but it is interrupted in part of its inner course (Fig. 3j).

Table 1. Mean of measurements of the colonies.

\begin{tabular}{ccc}
\hline \multicolumn{3}{c}{ Lithostrotion termieri } \\
\hline Specimen & Number of major septa & Tabularium diameter \\
AKR1-02 & 27.4 & 6.8 \\
AKR1-03 & 28.2 & 7.7 \\
AKR1-04 & 31.8 & 7.6 \\
WKH-1 & 27.1 & 7.6 \\
\hline
\end{tabular}

The columella is stout and spindle-shaped, much thicker than usual in the genus. The thickening is variable but present in every specimen (Fig. 3j). It is in contact with many major septa and in continuity with the counter septum. Where not shortened, the cardinal septum is also continuous with the columella (Fig. 3a).

The dissepimentarium is mainly composed of interseptal regular dissepiments. The dissepiments are more irregular in the external part of the dissepimentarium, passing to lonsdaleoid dissepiments in some instances (Fig. 3k). Two to four rows of slightly angular dissepiments are closely packed in the inner part of the dissepimentarium (Figs 3j-k). In longitudinal section, the dissepiments are small and globose. They are declined to the tabularium in variable angles, which increase from $50^{\circ}$ to $80^{\circ}$ near the dissepimentarium/tabularium boundary (Figs 3b, c, e, f, h, i); however, they are sub-horizontal near the outer wall.

The tabulae are incomplete. The general shape is conical, declined from the columella to the dissepimentarium, but tabellae may be flat, concave and convex (Figs 3b, c, e, f, h, i). They are not very densely packed, numbering between 10 and 15 each $\mathrm{cm}$. A biform tabularium is present.

Microstructure is entirely composed of fibres. The wall, septa and axial columella are trabecular (Fig. 3i). The tabulae and dissepiments are microgranular if thin, fibrous in the thickened parts.

Remarks. The main diagnostic feature of the new species is the large size of its corallites. A morphologically close species is L. araneum (McCoy, 1844) from which it differs by much larger dimensions of corallite and tabularium diameters, more numerous major septa and shorter cardinal septum. The arrangement of septa, dissepiments and axial structure is very consistent, with very little variation. The most variable features are: (i) the tabulae, which may be almost complete in some corallites (Fig 3b-c) but highly divided in others (Figs 3e-f), (ii) the relationship between diameter/number of septa that is higher in specimen AKR1-4 than in specimens AKR 1-2 and 3 (Fig. 2), and (iii) the thickening of the septa and columella that is variable in corallites of a single colony (Fig. 3a) and more conspicuous in colony AKR1-4 (Fig. 3g) than in the holotype.

Figure 3. Lithostrotion termieri Rodríguez \& Somerville. (a-c) Specimen DPM AKR1-2, holotype. a) Transverse section. b-c) Longitudinal sections. (d-f) Specimen DPM AKR1-3, paratype. d) Transverse section. e-f) Longitudinal sections. (gi) Specimen DPM AKR1-4, paratype. g) Transverse section. h-i) Longitudinal sections. (j) Detail of the axial zone, specimen AKR1-4. Note the thickening of septa and the close packing of slightly angular dissepiments in the tabularium/ dissepimentarium boundary; the shortening of the cardinal septum and the length of most major septa reaching the thickened columella. (k) Detail of the dissepimentarium, specimen AKR1-2, showing the irregular trajectory of the septa and irregular dissepiments in the periphery of the corallite. (l) Detail of the septal microstructure, specimen AKR1-2, showing the trabeculae in longitudinal section. Scale bar in the middle of the figure valid for all pictures except $\mathrm{j}, \mathrm{k}$ and $\mathrm{l}$. 
Lithostrotion termieri has several features in common with L. potii Denayer 2014 from the lower Viséan of NW Turkey, in its similar size and number of septa, and also $L$. sp. from the upper Viséan of NW Turkey (Denayer 2014; fig. 16BC). However, it can be distinguished from L. potii by its thicker spindle-shaped columella, longer and thicker spindle-shaped major septa, many of which reach the columella, longer minor septa that extend into the tabularium, and shorter cardinal septum in a cardinal fossula. It has some affinity with $L$. sp., which has longer major septa, although they do not reach the axis, and minor septa that just enter the tabularium, but the thin lath-like columella is more comparable to L. potii. Similar colonies with the same measurements have been recorded in the Campine Basin, Belgium (Julien Denayer, personal communication). Those specimens differ from $L$. termieri in having a thinner and more irregular columella, thinner and sometimes discontinuous septa, more irregular dissepimentarium containing lonsdaleoid dissepiments in some corallites. The dissepiments are larger and more inclined than in L. termieri.

\section{DISCUSSION}

L. termieri poses some questions from the palaeobiogeographic and evolutionary points of view. Up to now, there are only two occurrences of this taxon in spite of many studies on rugose corals of similar age in the Azrou-Khenifra Basin (Fig. 1b). Many outcrops in an extensive region of this basin comprising Asbian to Bashkirian rocks have been studied (Said et al., 2007, 2013; Aretz \& Herbig, 2010; Rodríguez et al., 2012, 2015, 2016a; Somerville et al. 2012), but no additional occurrences of this species has been recorded. It has not been recorded in other studied basins from North Africa (Fig. 1a), such as Jerada (Aretz, 2010), Tindouf (Rodríguez et al., 2013a, b), Tafilalt (Aretz et al., 2013) and Béchar (Semenoff-Tian-Chansky, 1985; Aretz, 2011) or in West European regions (Poty, 1981, 1984; Mitchell, 1989; Somerville, 1997; Rodríguez et al., 2002; Denayer et al., 2011; Rodríguez et al., 2016b). Consequently, the new species must be regarded at present as endemic in the Azrou-Khenifra Basin.

L. termieri is one of the largest known species of the genus and probably evolved from $L$. araneum with which it co-occurs in Akrab. It represents an opposite evolutionary trend to that described by Poty (1984) in the upper Viséan, of decreasing size in corallite diameter and reduction in the number of major septa ( $L$. araneum $\rightarrow$ $L$. vorticale $\rightarrow L$. decipiens $\rightarrow L$. maccoyanum). Instead, $L$. termieri shows an increase in corallite diameter and number of major septa. The presence of both trends simultaneously in the late Viséan (cf. Denayer, 2014) is also shown by the fasciculate genus Siphonodendron (Poty, 1984; Denayer, 2014).

L. termieri shows several characteristics in common with the largest species of the genus Siphonodendron (S. scaleberense Nudds \& Somerville, 1987), notably in possessing a shorter cardinal septum in an open cardinal fossula. This emphasises the distinct bilateral symmetry in mature corallites in the cardinal-counter septal plane, aligned with the columella.

\section{CONCLUSIONS}

The new species Lithostrotion termieri from the AzrouKhenifra Basin is erected and described. It seems to have evolved from Lithostrotion araneum, the morphologically closest previously known species, in the upper Viséan (Asbian), which has been recorded in the same outcrop. It has similarities with the other large-sized cerioid species Lithostrotion potii from NW Turkey, but is distinguished by thicker and longer septa and thick columella. At present, Lithostrotion termieri must be regarded as endemic.

\section{ACKNOWLEDGEMENTS}

This research received support from the Research project CGL2012-30922BTE of the Spanish Ministry of Research and Innovation and the SYNTHESYS Project, which is financed by European Community Research Infrastructure Action under the FP7 "Capacities" Program. The authors thank the cooperation of the Department of Mines and Development of the Ministère de l'Energie et des Mines of Morocco. The thin sections used for this study have been prepared by Isabel Díaz Mejías. We are most grateful to reviewers Markus Aretz and Julien Denayer for their very constructive comments. We also thank Julien Denayer for making available unpublished illustrations of Belgian lithostrotionid specimens.

\section{REFERENCES}

Aretz, M. 2010. Rugose corals from the upper Viséan (Carboniferous) of the Jerada Massif (NE Morocco): taxonomy, biostratigraphy, facies and palaeobiogeography. Palaeontologische Zeitschrift, 84, 323-344; doi: 10.1007/ s12542-009-0046-0.

Aretz, M. 2011. Corals from the Carboniferous of the central Sahara (Algeria): the collection of "Marie Legrand-Blain". Geodiversitas, 33, 581-624; doi: 10.5252/g2011n4a3. 
Aretz, M. \& Herbig, H.G. 2010. Corals from the Viséan of the southern Azrou-Khénifra Basin (Carboniferous, Central Moroccan Meseta). Palaeoworld, 19, 295-304; doi: 10.1016/j.palwor.2010.08.003.

Aretz, M., Denayer, J. \& Mottequin, B. 2013. Preliminary data on Viséan (Carboniferous) corals and brachiopods from the strata between the Djebel Begaa and the Gara El Itima (Eastern Tafilalt, Morocco. International Field Symposium «The Devonian and Lower Carboniferous of northern Gondwana», 87-94.

Denayer, J., Poty, E. \& Aretz, M. 2011. Uppermost Devonian and Dinantian rugose corals from Southern Belgium and surrounding areas. In: Field Guide $11^{\text {th }}$ International Symposium on Fossil Cnidaria and Porifera (eds Aretz, M. \& Poty, E.). Liège 2011. Kolner Forum Geologie und Paleontologie, 20, 151-201.

Denayer, J. 2014. Viséan Lithostrotionidae (Rugosa) from Zonguldak and Bartin (NW Turkey). Bulletin of Geosciences, 89, 737-771; doi: 10.3140/bull.geosci.1496.

Ehrenberg, C.G. 1834. Beiträge zur physiologischen Kenntniss der Korallentiere im allgemein und besonders des rothen Meeres, nebst einem Versuche zur physiologischen Systematik derselben. Physiologische abhandlungen der könige Akademie von Wissenschaften Berlin, 1832, 225-380.

Fleming, J. 1828. A History of British Animals. Beel and Bradfute, Edinburgh, 565 pp.

Frey, H. \& Leuckart, C.G.F.R. 1847. Beiträge zur Kenntniss Wirbelloser Thiere mit Besonderer Berucksichtigung der Fauna des Norddeutschen Meeres. Verlag von Friedrich Vieweg und Sohn, Braunschweig, 170 pp.

Hill, D. 1981. Rugosa and Tabulata. In: Treatise on Invertebrate Paleontology Part F (Supplement 1) (ed. Teichert, C.). Geological Society of America and University of Kansas Press, Boulder Colorado and Lawrence, Kansas (2 vols), 1-762.

McCoy, F. 1844. A Synopsis of the Characters of the Carboniferous Limestone Fossils of Ireland. Dublin, 5-207.

McCoy, F. 1849. On some new genera of Palaeozoic Corals and Foraminifera. Annals and Magazine of Natural History, Series 2, 1-20, 119-136.

Milne-Edwards, H. \& Haime, J. 1850-1855. A Monograph of the British fossil corals 1850 (p.1-71), 1852 (p.147-210), 1853 (p. 211-244), 1855 (p.245-299). Palaeontographical Society, London.

Milne-Edwards, H. \& Haime, J. 1851-1855. Monographie des Polypiers Fossils des Terrains Palaeozoiques, Précédée d'un Tableau General de la Classification des Polypes. Archives du Museum d 'Histoire Naturelle de Paris, Paris, 502 pp.

Mitchell, M. 1989. Biostratigraphy of Viséan (Dinantian) rugose coral faunas from Britain. Proceedings of the Yorkshire Geological Society, 47, 233-247; doi: 10.1144/ pygs.47.3.233.

Nudds, J.R. \& Somerville, I.D. 1987. Two new species of Siphonodendron (Rugosa) from the Viséan of the British Isles. Proceedings of the Yorkshire Geological Society, 46, 293-300; doi: 10.1144/pygs.46.4.293.
Orbigny, A.d'. 1852. Cours Élémentaire de Paléontologie et de Géologie Stratigraphique. Victor Masson, Paris, 2(1), $382 \mathrm{p}$.

Poty, E. 1981. Recherches sur les Tétracoralliaires et les Hétérocoralliaires du Viséen de la Belgique. Mededelingen Rijks Geologische Dienst, 35, 1-161.

Poty, E. 1984. An evolutionary pattern for the Western European Lithostrotionidae. Palaeontographica Americana, 54, 465-469.

Rodríguez, S. 1984. Corales rugosos del Carbonífero del Este de Asturias. Tesis Doctoral Universidad Complutense de Madrid. 109 (84), 1-528.

Rodríguez, S., Hernando, J.M. \& Rodriguez-Curt, L. 2002. Estudio de los corales lithostrotiónidos del Viseense (Misisipiense) de la Unidad de la Sierra del Castillo (Córdoba, España). Revista Española de Paleontología, 17, 13-36.

Rodríguez, S., Somerville, I.D., Said, I. \& Cózar, P., 2012. Late Viséan coral fringing reef at Tiouinine (Morocco): implications for the role of rugose corals as building organisms in the Mississippian. Geological Journal, 47, 462-476; doi: 10.1002/gj.2452.

Rodríguez, S., Said, I., Somerville, I.D. \& Cózar, P. 2013a. An upper Viséan (Asbian-Brigantian) and Serpukhovian coral succession at Djebel Ouarkziz (northern Tindouf Basin, southern Morocco). Rivista Italiana di Paleontologia e Stratigrafia, 119, 3-18.

Rodríguez, S., Somerville, I.D., Said, I. \& Cózar, P. 2013b. Rugose corals from a Carboniferous biostrome in the Tindouf Basin, S. Morocco. Spanish Journal of Palaeontology, 28, 255-284.

Rodríguez, S., Said, I., Somerville, I.D., Cózar, P. \& Coronado, I. 2015. Description of the Serpukhovian rugose and tabulate corals from Idmarrach and Tirhela Formations (Adarouch, Morocco). Boletín de la Real Sociedad Española de Historia Natural, Sección Geológica, 109, 71-101.

Rodríguez, S., Said, I., Somerville, I.D., Cózar, P. \& Coronado, I. 2016a. Serpukhovian coral assemblages from Idmarrach and Tirhela Formations (Adarouch, Morocco). Geologica Belgica, 19, 29-42; doi: 10.20341/gb.2015.019.

Rodríguez, S., Somerville, I.D., Cózar, P., Coronado, I. \& Said, I. 2016b. Inventory and analysis of the distribution of Viséan corals from the Guadiato Area (Córdoba, SW Spain). Spanish Journal of Palaeontology, 31, 181-220.

Said, I., Berkhli, M. \& Rodríguez, S. 2007. Preliminary data on the coral distribution in the Viséan from Adarouch Area, Central Meseta (Morocco). Schriftenreihe der Erdwissenschaftlichen Kommissionen, 17, 353-363.

Said, I., Somerville, I.D., Rodríguez, S. \& Cózar, P. 2013. Mississippian corals from the Khenifra area, central Morocco: variation in assemblages related to changes in facies and paleoecology. Gondwana Research, 23, 367-379.

Salée, A. 1913. Formes nouvelles du genre Caninia. Bulletin de la Société belge de Géologie, 26, 41-49.

Semenoff-Tian-Chansky, P. 1974. Recherches sur les Tétracoralliaires du Carbonifère du Sahara Occidental. 
Editions du Centre Nationale de la Recherche Scientifique. Serie 6, Science de la Terre, 30, 1-316, Paris.

Semenoff-Tian-Chansky, P. 1985. Corals. In: The Carboniferous of the World, II, Australia, Indian Subcontinent, South Africa, South America and North Africa. (eds Wagner, R.H., Winkler-Prins, C.F. \& Granados, L.F.). IUGS Publication 20, 374-381.

Somerville, I.D. 1997. Rugose coral faunas from Upper Viséan (Asbian-Brigantian) buildups and adjacent platform limestones, Kingscourt, Ireland. Boletín de la Real Sociedad Española de Historia Natural, Sección Geológica, 92, 35-47.
Somerville, I.D., Rodríguez, S., Said, I. \& Cózar, P. 2012. Mississippian coral assemblages from Tabainout mudmound complex, Khenifra area, Central Morocco. Geologica Belgica, 15, 308-316.

Termier, G. \& Termier, H. 1950. Paleontologie marocaine II. Invertebrés de l'ère Primaire. Foraminifères, spongaires et coelentérés. Notes du service geologique du Maroc, $73,1-220$.

Termier G., Termier, H. \& Vachard, D. 1975. Recherches micropaléontologiques dans le Paléozoïque du Maroc central. Cahiers de Micropaléontologie, 4, 1-99. 